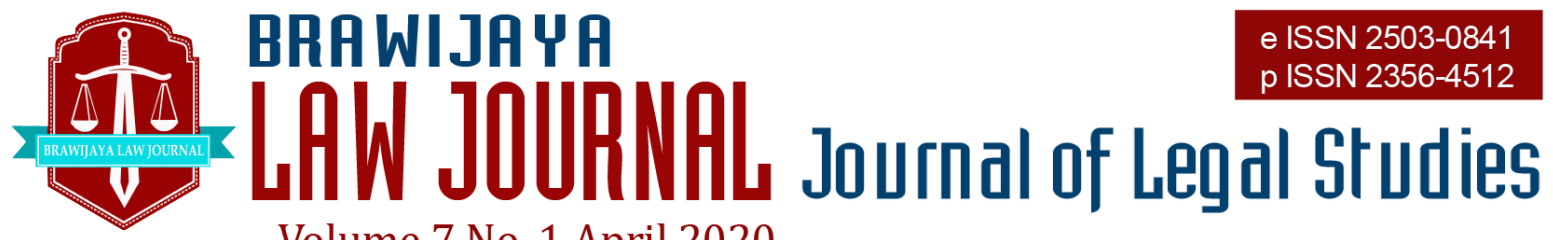

Volume 7 No. 1 April 2020

Nationally Accredited No. 30/E/KPT/2018 Dated 24th October 2018

This work is licensed under a Creative Commons Attribution-NonCommercial 4.0 International License

\title{
Functionalization of the Village Head as Customary Leader in the Social Field in South Sumatra
}

\author{
Abdullah $^{\mathrm{a}}$, KN. Sofyan Hasan ${ }^{\mathrm{b}}$, Iza Rumesten RS. ${ }^{\mathrm{c}}$, Taroman Pasyah ${ }^{\mathrm{d}}$ \\ ${ }^{a}$ Law Faculty Of Sriwijaya University \\ Email: abdullahgofar12@yahoo.co.id \\ bLaw Faculty Of Sriwijaya University, \\ Email: kn.sofyan_hasan@yahoo.co.id \\ ${ }^{c}$ Law Faculty Of Sriwijaya University \\ Email: rumesten_iza@yahoo.com, \\ ${ }^{\mathrm{d}}$ Law Faculty Of Sriwijaya University \\ Email: taromanp@yahoo.com
}

Submitted : 2019-01-05 | Accepted : 2020-04-15

\begin{abstract}
The presence of the New Order government has brought about changes in the lowest level of government, which fairly basic leads to some institutional unification and uniformity. This has resulted in the loss of legal community units in Indonesia. The loss of indigenous community units began with the beginning of Law Number 5 of 1979 on Village Governance as a follow-up to the birth of Law Number 5 of 1974 on the Principles of Government in the Regions. Correspondingly, in South Sumatra, the lowest institutional governance tool, which is also a territorial indigenous community unit called Marga was abolished through the Decree of the Governor of South Sumatra No.142/ KPTS/1983. With the abolition of the Marga, it implies the loss of a typical indigenous institution of South Sumatra, which was merged into the Village institution as stipulated in Law Number 5 of 1979 on Villages. As a result, all the lowest institutions in South Sumatra switched their names to villages including, their functions and authorities. The removal of the Marga government and being replaced with the Village, has resulted in the loss of social functions and the function of resolving disputes customarily manner in the community. The function shift of the village head was not necessarily the transfer of the authority of the pesirah Margahead to the village head in resolving arising problems in the community. As a result of this obscurity of the function, all arising problems in the community should resolve by the formal public law determined by the state. This results in an imbalance in the lowest community, including in villages in South Sumatra, to break the chain, the research framework has carried out to answer these problems.
\end{abstract}

Keywords: functionalization; village head; marga, South Sumatera.

\section{INTRODUCTION}

Law Number 6 of 2014 on Villages, affirms in article 1 paragraph 1 that the village as a legal community unit that has territorial boundary is authorized to regulate and administer government affairs, the local community interests based on community initiatives, right of the origin, and traditional 
right which is recognized and respected in the government system of the Republic of Indonesia. The village has the right of the origin and traditional right in regulating and managing the interests of the local community and contributing to achieving community prosperity.

As the lowest layer of the government structure, community activities in the village should have the opportunity to develop their potential. Indeed, a village is a necessary and connected part of a hierarchy of state structures, since there will never be a country without having the smallest parts ${ }^{1}$. The development of the Indonesian Constitution is inseparable from the history that occurred during pre-independence until postindependence. Especially for the Village Governance, the long history of its development began with the rule of the Dutch East Indies Colonial Government, namely Island Ministry of Ordinance (IGO) and Inlands Gemeente Ordonnantie Buitengewesten (IGOB) and the rules locally made by each region ${ }^{2}$. After independence, the emergence of Law Number 22 the Year 1948 and Law Number 1 the Year 1957 and Law Number 18 the Year 1965 on Regional Autonomy, had maintained the character and feature of the lowest government by the respective local legal community. However, the presence of the New Order government has brought about changes in the lowest level of government that are fairly basic leads to some institutional unification and uniformity.

The South Sumatra Customary Legal Society recognizes the term levels in which there are superior conventional legal society and subordinate usual legal society, who are subject to the superior customary legal society or indigenous people of the area ${ }^{3}$. In the view that applies in indigenous society, not all legal events and violations of law committed and detrimental to fellow conventional law society as well as harming outside society in other customary legal society, must be settled using state law, but better and wiser to use local customary law. Adat broadly refers to customary laws of different Indigenous groups and is one of the three components of legal plurality in Indonesia alongside Civil Law and Sharia Law. Adat law is "a complex of rights and obligations tying together history, land law in a specifically Indonesian way, there are no uniform Adat laws as every locality has culturally specific rules to meet the needs of the community ${ }^{4}$, especially in the social field.

Table 1. Community Affairs

\begin{tabular}{cll}
\hline No & $\begin{array}{l}\text { Customs in the Social Field of Customary Legal } \\
\text { Society of South Sumatra }\end{array}$ & Annotation \\
\hline 1 & $\begin{array}{l}\text { Mutual assistance in opening plantation land } \\
\text { tanahume) }\end{array}$ & Still applicable in some regions \\
2 & Mutual assistance in the alms wedding ceremony & Still applicable in some regions \\
3 & Mutual assistance in harvesting plantation products & Still applicable in some regions \\
4 & Mutual assistance in building Mushollah and mosque & Still applicable in some regions \\
5 & Tepungtawar (foster brother) & Still applicable in some regions \\
6 & Keramasandusun (safety prayer for hamlet) & Still applicable in some regions \\
7 & Pancung Alas & Still applicable in some regions \\
\hline
\end{tabular}

Source: South Sumatra Community Informants

Moh. Fadli dkk, Pembentukan Peraturan Desa Partisipatif (Head To A Good Village Governance), (Malang; UB Press, Februari, 2013), 3.

2 Ni'matul Huda, Hukum Pemerintahan Desa (Dalam Konstitusi Indonesia Sejak Kemerdekaan Hingga Era Reformasi), (Malang; Setara Press, Maret, 2015), 94.
3 Soerjono Soekanto, Hukum Adat Indonesia, ( Jakarta; PT Raja Grafindo Persada, Agustus 2016), 141

4 Boag, Carly, 'A Comparative Study Of The Legal Frameworks Facilitating Indigenous Land Management In Postcolonial Societies: Indigenous Australia And Indonesian Adat Law', (2016) 3(2) Brawijaya Law Journal, 125-150 
Mutual assistance is a form of social field that is a part of customs in the life of the indigenous peoples of South Sumatra, such as jointly establishing places of worship, mutual assistance in the opening of plantation land, and the implementation of weddings. In certain customary legal societies, when there is an act of adultery relationship committed by a man and a woman (unmarried couple), then both must be responsible for the village by carrying out the "keramasan dusun." Furthermore, in the South Sumatran customs, also known as the "tepung tawar," when there is a dispute or problem in the customary legal society.

The settlement of disputes carried out by traditional leaders in the South Sumatra custom society has called by naming or terming "tepung tawar," "ngangkan salah," "bedulur," "bepajar," and others. The final procession has usually carried out with a ballot and thanksgiving ceremonies in the form of alms from two large families by involving the relevant community and traditional leaders. In customary law, dispute resolution is not only seen from the interests of public law and private law which stress the principle of justice losing and winning but more that it becomes the authority of the custom leader (Pasirah) who should restore the balance if there is any shock inside the community.

However, by the birth of Law Number 5 of 1979 on Village Governance as a followup to the beginning of Number 5 of 1974 on the Principles of Governance in the Regions, it has eliminated indigenous peoples, or customary legal societies, including in South Sumatra, one of the impacts is the uniformity of all the lowest governance models in all of Indonesia, and the loss of the formal characteristics and features of the society in South Sumatra. In line with that in South Sumatra, the lowest institutional governance instrument, which is also a territorial indigenous community unit called Marga was abolished through the Decree of the Governor of South Sumatra No.142 / KPTS / 1983. With the abolition of the Marga, it

\footnotetext{
5 Kompilasi Adat Istiadat, Banyuasin Sedulang Setudung, (Kabupaten Banyuasin Propinsi Sumatera Selatan; 2015), 2.
}

implies the loss of a typical indigenous institution of South Sumatra and merged into the Village institution as stipulated in Law Number 5 of 1979 on Villages. ${ }^{5}$

All the lowest institutions in South Sumatra switched their names to villages, including their functions and authorities. The removal of the Marga government ${ }^{6}$ and being replaced with the Village brought about the loss of social functions and the function of resolving disputes traditionally in the community. The function of the village head was not necessarily the transfer of the authority of the surname head to the village head in resolving problems arising in the community. As a result of the obscurity of the function, all the problems that arise in the community, the solution must use the public formal legal provided by the state. Such a solution slowly eliminates the sense of togetherness, brotherhood, and feelings of love in the community.

Law Number 6 of 2014 on Villages, the authority of the village head is more directed as a manager who is directed to manage the village government independently with the making of policies based on the principle of subsidiarity, namely the determination of local scale authority and local decision making for the benefit of the village community. The principle of kinship is the habit of the villagers as part of a large family unit in the village community. The principle of deliberation, namely the decision-making process that concerns the interests of the village community through discussions with various interested parties. The principle of democracy, particularly the system of organizing the village community in a system of government, carried out by the village community or with the approval of the village community. As well as the principle of independence, which is a process carried out by the Village Government and the village community to carry out an activity to

6 Marga adalah kesatuan pemerintahan yang terendah berdasarkan hukum adat. Ni'matul huda, Note, 93. 
meet their needs with their abilities. ${ }^{7}$ That the village government is the organizer of government affairs and local community interests in the government system of the Unitary State Republic of Indonesia ${ }^{8}$. Based on the description above it can be explained, that with the issuance of Law Number 6 of 2014 on Villages, it has provided enormous opportunities for the Village Government to regulate and run the lowest wheels of government in the Republic of Indonesia's constitutional system independently for the realization of a just, affluent and prosperous society. With its independence, the Village Head can reinstate customary law in his system of government.

The Village Government led by a Village Head can act and can issue policies, and establish authority. Then, as a custom leader, the Village Head must regulate and resolve the existence of a law that develops in the community.

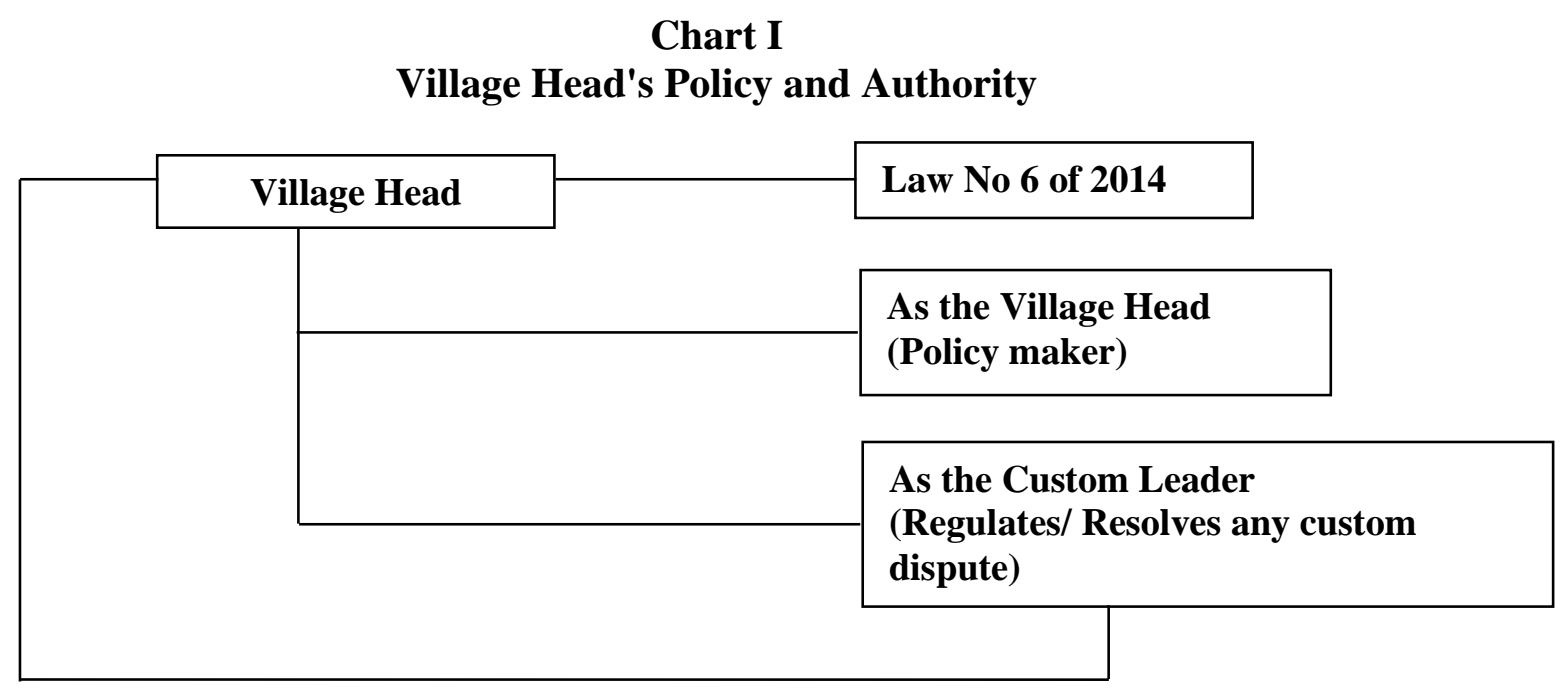

From the chart above can be noted that Law No 6 of 2014 about the village gives a double function to the village head. The roles are: first as the head of a village that manages the administrative affairs related to the interests of the village, and second as a culture figure ("Adat figure") that helps to control and resolve custom disputes or customary legal issues. These two duties must be played by the head of the village in organizing and managing the village community. Both functions are very important to be done by a village head to create peace and prosperity in the region.

Since not all problems arising from the community must have resolved using the state law with the institutions provided by the State. However, due to the absence of a law that departs from local wisdom, so far, it has required the community to resolve disputes and violations of law by using the state's formal legal channels. To break the chain, so the research framework was carried out to answer the problem. In other words, this research, is carried out is to help the State in resolving problems that arise from the community, in particular, the people of South Sumatra through the available custom tools; as well as how to function and give a role to the Village Head in the social field in resolving disputes among the people in his area using conventional approaches and settlement, to restore the balance in the society in the national legal order. In the empirical reality, there are sometimes many problems that arise by the indigenous peoples of Indonesia when customary law has confronted with positive law. For example, when traditional rights of the community

8 Yusnani Hasyim Zoem et.al, Hukum Pemerintahan Daerah, (Jakarta; Raja grafindo Persada, Maret 2017), 132. 
relate to the interests of investors through state legal means. ${ }^{9}$

\section{LEGAL MATERIALS METHOD}

AND

This paper use empirical method to answer the legal issues that occur. Moreover, this paper also used sampling direct interview technique to collect the data in several villages, regency and city in South Sumatra. The researcher interviews the sources relating the customary law in the interviewees village such as the implementation, development, and practice of customary law in South Sumatra.

The locations of research are located in Banyu Asin Regency; Palu Beruang Village and Kayu Ara Village in Ogan Komering regency; Musi Rawas Regency; Prabu Hamlet Village and Sungai Medang Village in Prabu Mulih City; Lubuk Linggau City; Pagar Alam City.

\section{RESULTS AND DISCUSSION}

\section{The Village Head Functions}

\section{a. Customary Disputes Development in the Social Field \\ and}

Customary law as a positive law has a typical characteristic that is, considerably unwritten, but its values exist and apply in the lives of the custom society who enforce it. Customary law applies in a limited scope, that is, only applies to a custom society where the customary law lives or has located, and in this situation, it is very possible that each custom society might have different customary laws from one another, including in southern Sumatera. This attracts the writer to study more deeply related to the existence of customary law, including disputes that occur in the community that can be resolved only through customary law. This study is focused only on customary disputes in the field of society and has also directed to areas that were considered capable of providing information relating to any customer disputes that often occur in the community, including:

\section{1) Customary Disputes and Settlements in Banyu asin Regency}

Table 2. Customary Disputes and Settlements in Banyu asin Regency

\begin{tabular}{|c|c|c|c|c|}
\hline No & Customary Terms & Main Problem & Settlement & Annotation \\
\hline 1 & $\begin{array}{l}\text { Bangun (timbang } \\
\text { bangun) }\end{array}$ & $\begin{array}{l}\text { Has lost someone's } \\
\text { life }\end{array}$ & Consensus & $\begin{array}{l}\text { Giving some } \\
\text { money to the } \\
\text { family of the } \\
\text { deceased }\end{array}$ \\
\hline 2 & $\begin{array}{l}\text { Basuh Dusun (tepung } \\
\text { dusun) }\end{array}$ & $\begin{array}{l}\text { Has occurred } \\
\text { Adultery }\end{array}$ & $\begin{array}{l}\text { Agreement Consensus; } \\
\text { Village Head/and } \\
\text { Custom Leaders }\end{array}$ & $\begin{array}{l}\text { Slaughtering } \\
\text { buffaloes or } \\
\text { goats/doing deeds } \\
\text { worth to those }\end{array}$ \\
\hline 3 & Tekap malu & $\begin{array}{l}\text { Has violated the } \\
\text { honor of others which } \\
\text { is a customary } \\
\text { violation }\end{array}$ & Consensus & $\begin{array}{l}\text { Paying some } \\
\text { money as a form } \\
\text { of restoring honor } \\
\text { in question }\end{array}$ \\
\hline 4 & Tepung tawar & $\begin{array}{l}\text { Have occurred } \\
\text { disputes that violate } \\
\text { the custom }\end{array}$ & Consensus & $\begin{array}{l}\text { Giving in the form } \\
\text { of money as a } \\
\text { form of peace }\end{array}$ \\
\hline
\end{tabular}

Data results: based on data taken from informants in two villages in Banyuasin District, namely: Langkan Village and Pulau Harapan Village

9 M. Syamsudin, 'Beban Masyarakat Adat Menghadapi Hukum Negara', (2008) 15(3 Juli 2008) Jurnal Hukum, 338-351. 
From the list above, we can know that in Banyuasin regency the customary dispute and settlements is still alive.

Annotation:

1. Bangun (timbang bangun), is a gift in the form of money to the family of the deceased as a result of consensus agreements from the family, which causes the loss of one's life.

2. Basuh Dusun (tepung dusun), is to implement hamlet offerings by slaughtering buffaloes or goats or to do other acts of equal value with the cost of the offerings based on consensus agreements led by the Village Head/Lurah and Custom Leaders since adultery has occurred, all fees are charged to the perpetrators/families of the local community based on an agreement.

3. Tekap malu is the giving of a sum of money by someone who violates the honor of another person, which is a customary violation, based on deliberation and consensus to restore the respect concerned and the peace of the community.

4. Tepung tawar is money paid or goods are given as a result of consensus agreement, which is a form of peace
Villagers who choose to solve the legal issues they face by using Adat laws in their area to resolve legal problems in an Adat Law, dependent on the legal issues of what they are facing. As in the area of banyuasin people can apply customary law in terms of murder (Bangun), adultery (basuh Dusun), violation of other honor (Tekap Malu), and violation of customary (Tepung tawar). The problem can also be done with the party's concortus so that the two parties can make peace again. However, there is no prohibition for villagers to choose to use positive laws as a means of resolving the problems they face if they consider the law to be solved legally.

\section{2) Customary Disputes and Settlements in Ogan Komering Ilir Regency}

Disputes in the area of custom society that occur in Ogan Ilir District are not much different from what happened in Banyuasin District, but the terms and names are a little bit different. Common disputes and problems in the social field that took place in Ogan Komering Ilir District, among others, data are taken from Pulu Beruang and Kayu Ara Villages, Ogan Komering Ilir Regency.

Table 3. Customary Disputes and Settlements in Ogan Komering Ilir Regency First Village Pulu Beruang Village in Ogan Komering Ilir Regency

\begin{tabular}{llll}
\hline Customary Terms & Main Problem & Settlement & Annotation \\
\hline Memegang gadis & $\begin{array}{l}\text { Has violated the honor } \\
\text { of others which is a } \\
\text { customary violation }\end{array}$ & $\begin{array}{l}\text { Promotion the } \\
\text { principle of family }\end{array}$ & $\begin{array}{l}\text { Payment of fines made } \\
\text { by the perpetrator to the } \\
\text { victim, witnessed by } \\
\text { the village head, } \\
\text { customary leaders and } \\
\text { the police. }\end{array}$ \\
\hline
\end{tabular}

Data: based on data taken from informants in two PuluBeruang villages in OgankomeringIlir Regency

Local people tend to prefer solving problems they experience using local tools or customary law. By the customs of the local community, the village head is considered capable of resolving disputes and problems that exist without exception. This is done by the community to prevent and avoid unilateral decisions or arbitrariness that can harm one of the parties to the dispute. Including the relation to the problem of "memegang gadis," as above mentioned, the village of Pulu Beruang establishes a customary rule that still maintained today. When there has been a violation of other people's honor, which is a customary violation, the resolution has settled by custom and family. Usually, after the issue has resolved, the final result will be taken with a fine to one of the injured parties. Then, in the payment of the fine, the police also usually included as witnesses besides the relevant parties. Indigenous peoples have the 
same pattern in resolving conflicts in the community, namely controlling life in the community and imposing sanctions if violated, so recovery is very effective. ${ }^{10}$ Sulastriyono said customary law could also be used as a source of law by judges if the law ordered, ${ }^{11}$ because customary law as a legal reality is the original Indonesian legal material which is material for the formation of Indonesian positive law. ${ }^{12}$

\section{3) Customary Dispute and Settlements in Kayu Ara Village in Ogan Komering Ilir Regency}

Table 4. Customary Disputes and Settlements in Ogan Komering Ilir Regency Second Village Kayu Ara Village in Ogan Komering Ilir Regency

\begin{tabular}{llll}
\hline Customary Terms & Main Problem & Settlement & Annotation \\
\hline Land Ownership & $\begin{array}{l}\text { Do not have a } \\
\text { certificate, there are no } \\
\text { signs of ownership }\end{array}$ & $\begin{array}{l}\text { Consensus and family } \\
\text { principle }\end{array}$ & $\begin{array}{l}\text { When the landowner } \\
\text { can bring witnesses, the } \\
\text { land can be said to be } \\
\text { legal. }\end{array}$
\end{tabular}

Data: based on data taken from informants in two Kayu Ara Dalam villages in the District of Ogan komering Ilir

In line with what has stated above, it is related to the issue of "memegang gadis" in the village of Pulu Beruang, Ogan Komering Ilir Regency, in Kayu Ara village, it also assumed that the chief of village was considered capable of resolving disputes and problems without exception. Since when a dispute related to land ownership occurs, the settlement is carried out by involving local leaders.

Disputes and settlement of Indigenous debates in the social society that occur in East Ogan Komering Ulu Regency may not be too different from what happened in other regions. However, the concern is in line with the enactment of Law Number 5 of 1979 on Village Governance. Then followed by the issuance of the Decree of the Governor of South Sumatra No.142/KPTS/1983 on The Abolition of the Marga Governance. So, it has an impact on the loss of customary law gradually in custom society, including in East OKU Regency.

The term sanction in English called sanctions, while in Dutch the term sanctie

10 Desi Tamarasari, 'Pendekatan Hukum Adat Dalam Menyelesaikan Konflik Masyarakat Pada Daerah Otonomi', (2002) 2(1) Jurnal Kriminologi Indonesia., 37-47.

11 Lastuti Abubakar, 'Revitalisasi Hukum Adat Sebagai Sumber Hukum Dalam Membangun conceptualized as a sentence imposed on the perpetrator, while in the large Indonesian dictionary, sanctions mean:

a. Endorsement or confirmation; or

b. Actions or penalties for forcing people to keep agreements or obey laws; or

c. Actions (regarding the economy) as a punishment for a country

Based on the explanation above, it can explain, that sanctions are penalties set for persons/entities who violate the law, including in customary law, which has sanctioned for anyone who violates local custom prohibitions.

\section{4) Custom Development of Musi Rawas Regency}

The custom of Musi Rawas Regency is essentially a habit that applies to each custom society and village where the community resides. With today's development and progress, the customs in Musi Rawas Regency have experienced a shift that sometimes can eradicate the existence of the custom. 
Table 5. Custom Development of Musi Rawas Regency

\begin{tabular}{lll}
\hline No & Existing Customs & Extinct Customs \\
\hline 1 & Gotong Royong & Bringing chicken before the wedding \\
2 & Masak joda saat ada pernikahan & Single guitar \\
3 & Angkan-angkanan & Drain the river (shared fish harvest) \\
4 & Likokan & - \\
5 & Dekorasi & - \\
6 & Senjang & - \\
\hline
\end{tabular}

Annotation :

1. Gotong royong, is the custom of the local community, when there are wedding preparations, and takes care of the deceased.

2. Masakjoda (dodol) done when there is a marriage. Making joda (dodol) is a symbol of the happiness between the two parties who will hold a wedding party.

3. Angkan-angkanan, usually done if there are people who have the same name. So that those who have the same name no longer mention names when meeting but call sename. This means that the person who has formally represented becomes his own family even though he is not from the family.

4. Likokan is a single girl event, usually, this event has carried out before a wedding reception. Then, this activity is also usually carried out and also includes the prospective bride who has been picked up before with permission from the prospective bride's parents beforehand.

5. Dekorasi is an event carried out by creative local youth and young women to decorate the place where the wedding will take place.

6. Senjang is an activity that is usually carried out by the Father or the ladies with an answer to the rhyme and accompanied by music.

The list of custom development above in Musi Rawas Regency show that the custom in Musi Rawas still use by the community in the area. Many existing customs still be part of the local community live until this moment. For the example, "Gotong Royong" still exist, it usually happened when there are weeding preparation, cleaning the village and almost in every event in the village.

\section{Chart 2. Customary Sanctions in Musi Rawas Regency}

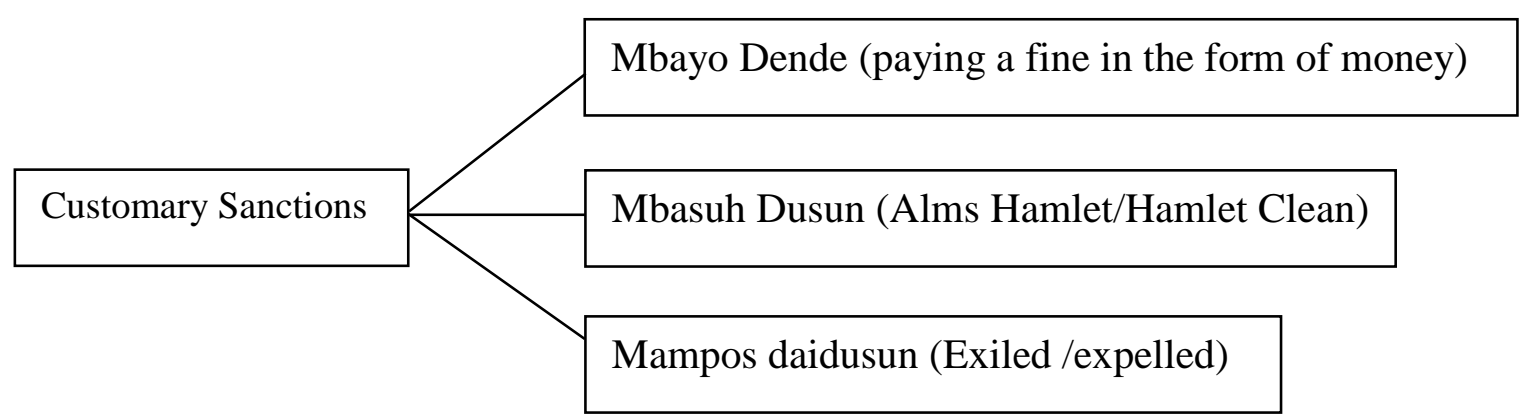

Annotation :

1. Mbayo Dende (paying a fine in the form of money), this customary sanction is usually carried out when there is a violation of local customary prohibitions, including in Musi Rawas, which requires the violator to fulfil the provisions. Because, these provisions have been discussed beforehand, among the Chief of Village, Customary leaders and the parties related to the case.
2. Mbasuh Dusun (Sedekah Dusun/Bersih Dusun), sanctions are imposed on people who have had relationships outside of marriage, so that local people assume that the hamlet or their place has been dirty as a result of these actions. Therefore, the local community is willing the village to be charitable.

3. Mampos daidusun (leaving the hamlet). 
From the chart above show that the Musi Regency not only have customary law to manage the society activities but also they have customary sanction for the person who violates the customary law. The customary sanction in Musi Rawas include paying fine (money), Hamlet cleaning, exiled from his/her hamlet. The amount of sanctions is given based on the type of infringement perpetrators have committed. Sanctions were decided based on a joint decision between the village head, the customary chairman, and the parties involved.

\section{5) Custom Development in Prabumulih Hamlet Village, Prabumulih City}

Prabumulih city as one of the cities in South Sumatra, which dissociated itself from the Muara Enim Regency in 2001, however, Prabumulih's status as a municipality, did not immediately eliminate the status of the village, especially the development of customary law that has existed so far.

The development of custom hereunder is taken from Prabumulih Hamlet Village, Kelurahan Prabumulih (Marga Rambang), and Sungai Medang Village, Kelurahan Sungai Medang (Marga Belide). The custom development in Prabumulih Vilage are:

Table 6. Custom Development of Prabumulih City First Village Prabumulih Hamlet Village

\begin{tabular}{lllll}
\hline No & Customary Terms & Main Problem & Settlement & Annotation \\
\hline 1 & Kawin Lari & Marriage & $\begin{array}{l}\text { Consensus and } \\
\text { family principles } \\
\text { To the authorities } \\
\text { (police) }\end{array}$ & $\begin{array}{l}\text { Presented by each } \\
\text { party, then } \\
\text { witnessed by the }\end{array}$ \\
$\begin{array}{l}\text { Village Head/ } \\
\text { Lurah }\end{array}$ \\
2 & Rukok panjang & Matchmaking & & $\begin{array}{l}\text { Returned to the } \\
\text { children, when they } \\
\text { are adults } \\
\text { A form of gratitude } \\
\text { from the event } \\
\text { owner }\end{array}$ \\
& $\begin{array}{l}\text { Panen padi (ngetam) } \\
\text { sedekah kebon }\end{array}$ & - & - & Using flowers \\
4 & $\begin{array}{l}\text { Mandi simburan or mandi } \\
\text { junub }\end{array}$ & $\begin{array}{l}\text { Customary } \\
\text { wedding ceremony }\end{array}$ & - & \\
\hline
\end{tabular}

Annotation :

1. Kawin Lari (belarianor minggat in Rambang language), in some cases, is settled in a family manner. However, in the Rambang area, it should be noted that there are two kinds of minggat, Minggat Terang is marriages which are regulated by custom, were at the time of the wedding the family wants to deliver out, both the groom and bride, before the wedding is held. Minggat Gelap is elopement, which cannot be blessed by parents or family.

2. In marriage customs, the Marga Rambanghas a uniquenesses, one of which is rukok panjang, a type of matchmaking from childhood that is carried out exactly as an adult. Starting from the customary inter-delivery and clothes worn and guests. However, this match has returned to the children who will grow up. If the children still love each other, then the marriage will take place. However, on the contrary, when these children do not like each other anymore, it does not become a problem for both parties.

From the table above show that several customary law that still exist. For the example "Kawin Lari" there are 2 way of settlement: first, the consensus between the bride and groom family with the chief of the village as the witnesses or usually as the mediator between the two families. Second, if the family did not want to settle the customary law, they usually bring the problem to the police. The other example is "Panen Padi (ngetam) sedekah kebon", this action is done to celebrate and gratitude toward God from the owner event. However, even the owner of the farm did not do the 
customary there is no punishment from the customary law.
6) Custom Development in Sungai Medan Village, Prabumulih City

Table 7. Second Village Sungai Medang Village

\begin{tabular}{llll}
\hline Customary Terms & Main Problem & Settlement & Annotation \\
\hline $\begin{array}{l}\text { Sedekah duson (sedekah } \\
\text { dusun) }\end{array}$ & - & - & The form of gratitude \\
& & & $\begin{array}{l}\text { from the event owner } \\
\text { which is carried out } \\
\text { once a year }\end{array}$ \\
\end{tabular}

Annotation :

1. Sedekah Duson (sedekah Dusun), is a charity which is held once a year and involves all citizens. All residents gather in the village hall and then work together to make a meal for the charity.

In the event of a dispute, the settlement has predominantly returned by the custom elders who are mediators to resolve the problem. Sungai Medang village does not have customary institutions, but, figure or seniority has highly upheld here, and it also has Customary Hall. In this Sungai Medang village, there is a customary law which is called sedekah mantah. Sedekahmantah is a form of punishment or consequence for violators of the rules that disturbs the community. The perpetrators must carry out rituals or obligations to give alms, with one canting rice, one egg, and one coconut. Then, the custom elders and village officials considered this as remorse, which witnessed by the family who was harmed by the perpetrator.

In SungaiMedangvillage, it also recognizes kualat penalties, meaning that when someone has promised not to do the same wicked thing, but in the future, it turns out that the action has repeated, then the action is called kualat. In addition to the kualat sentence, there are more penalties in the form of taboos that must not be violated, when someone has done sedekah bimam or sedekah duson. One of the restrictions is, after the sedekah bimam or sedekah duson, the community must remain silent without any activity for 3 (three) days, even if they hit nails using a hammer. If the taboo has violated, then there is a moral sanction that will occur, the kualat law will befall the person.

\section{7) Custom Development of Lubuk Linggau City}

The custom of the City of Lubuk Linggau is essentially a custom that applies to each custom society and village where the community resides. Customs in Lubuk Linggau City is not very different from the customs that develop in other areas, including customs that exist in Musi Rawas Regency. However, with today's development and progress, the custom has experienced a shift that sometimes can eradicate the existence of the custom

Table 8. Custom Development of Lubuk Linggau City

\begin{tabular}{|c|c|c|}
\hline No & Existing Customs & Extinct Customs \\
\hline 1 & Gotong Royong & $\begin{array}{l}\text { Bringing chicken } \\
\text { before the wedding }\end{array}$ \\
\hline 2 & $\begin{array}{l}\text { Masak joda saat ada } \\
\text { pernikahan }\end{array}$ & $\begin{array}{l}\text { Being paraded } \\
\text { around the village } \\
\text { after the marriage } \\
\text { contract }\end{array}$ \\
\hline 3 & Angkan-angkanan & Bridal shower \\
\hline 4 & Tepung Tawar & \\
\hline 5 & Besindo & - \\
\hline 6 & Cuci kampung & - \\
\hline 7 & Senjang & \\
\hline
\end{tabular}

Of the many customs in the City of Lubuk Linggau or known as the Sebiduk Semare area, they almost gradually disappeared by the time being. However, there still many customs exist in the area, for the example is "Cuci Kampung”, this activity usually involving almost all the people in the village to clean the village. The chief of the village become the leader for the activities in their village. Every person helps each other to make their village become comfortable and clean. 


\section{8) Custom Development in Pagar Alam} City

The people of Pagar Alam City or who are known as the Besemah people are very familiar with customary ways in their daily lives, and even, more they often use customary law as a dispute resolution media compared to positive law. Customary law that has considered having magical power makes it difficult for local people to abandon the law because, according to some of them when the customary law has abandoned, there will be a disaster due to the anger of the ancestors of the Besemah tribe. However, the status of the City of Pagar Alam as a municipality does not directly eliminate the status of the village, especially the development of the existing customary law so far. So that, even though the presence of Lurah who has been wrapped in the nuances of progress and development of the times, it does not eliminate the nuances and developments of prevailing customary law.

Table 9. Custom Development of Pagar Alam City

\begin{tabular}{lllll}
\hline No & Customary Terms & Main Problem & Settlement & Annotation \\
\hline 1 & $\begin{array}{l}\text { Bersikahduson } \\
\text { (hamlet cleaning) }\end{array}$ & $\begin{array}{l}\text { Kumpul kebo, } \\
\text { adultery }\end{array}$ & $\begin{array}{l}\text { Consensus and } \\
\text { family principles }\end{array}$ & $\begin{array}{l}\text { Slaughter of goats or } \\
\text { cows to clean the } \\
\text { hamlet from the anger } \\
\text { of ancestral spirits }\end{array}$ \\
2 & $\begin{array}{l}\text { Angkan-angkanan } \\
\text { keluarga }\end{array}$ & $\begin{array}{l}\text { Fights, accidents } \\
\text { (died) }\end{array}$ & $\begin{array}{l}\text { Consensus and } \\
\text { family principles }\end{array}$ & $\begin{array}{l}\text { Usually immediately } \\
\text { appointed as a brother, } \\
\text { or family }\end{array}$ \\
\hline
\end{tabular}

Annotation :

1. Bersikah duson is a sanction for cases of cohabiting (adultery) so that those who have carried out these actions are obliged to slaughter animals (cows or goats) that are known by the local community and are attended by the village head and local customary leaders, to avoid ancestral spirit anger according to their understanding.

2. Angkan-angkanan keluarga, this action is usually carried out when a dispute or death has occurred due to being hit by a car or motorbike.

\section{How the Village Chief Resolves the Disputes in the Social Field}

Based on the interviews relating to the implementation and practice of customary law in South Sumatra, in particular, in the districts and cities as the sample of this study, it is found that the functionalization of the village head as an official and customary leader in the social field in resolving disputes turned out to prioritize consensus and family principles.

\section{Chart 3. Dispute resolution by the Village Head}

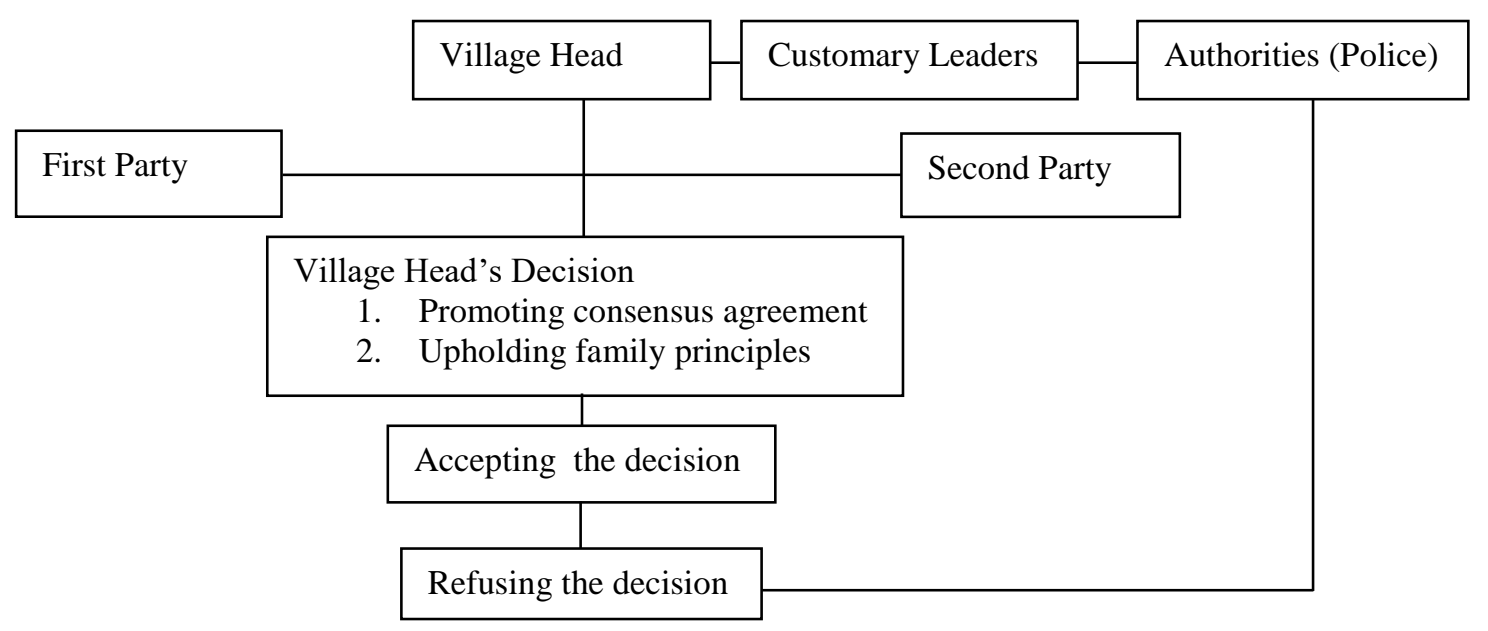


Based on the chart above, the parties to the dispute meet the head of the village to request mediation or to assist the parties in resolving their problems. The village chief in deciding the matter will take into consideration the family principle and mutual agreement.

However, the parties may receive part or all of the results of the village head's decision. If either party or both parties do not agree with the outcome of the ruling they may submit their problems to the government authorities who have the authority to complete it such as the police or any other court body.

Moreover, it can explain that the role of the Village Head in resolving cases that arise in the community is very strong. This is proven by, namely:

1) The community assumes that the village head is responsible for any problems that happen in the community he leads.

In this case the head of the village must be ready to any problem that arise in his/her village.

2) The community considers that the Village Head understands and can solve problems that occur in the community, even solutions that have carried out outside of customary law

The head of the village has responsibility to settle the dispute or problem that arise in his/her village. It could be cause by his/her community; his/her villager with other villager; or other villager with another villager that happened in his/her village. The Head of village shall be ready to settle the dispute or even cooperate with the other head of the village or even police and prosecutor to settle the problem that beyond his/her authority.

Villagers have a very high trust in the village head because, in solving each problem the village chief always puts forward discussion and upholds the principles of family. Therefore, if the villagers are faced with legal issues, they first ask suggestions from the head of the village to settle the problem that they are facing, whether it can be resolved through customary law or under the litigation to be resolved using positive law.

The selection of settlement by involving the village chief is considered to be one of the ways to keep citizens ' harmony and undelete can be completed quickly. Besides, the solution in this way also saves more costs incurred because there is no need to spend costs.

\section{CONCLUSION}

Based on the data and information from the field and related to the Functionalization of the Village Head as an Official and Customary Leader in the Social Field in South Sumatra, it can be concluded that, customary law and customs procedures are still applicable and developing in the lives of the people in South Sumatra, Indonesia. However, since it is not supported by the Indonesia rules and legal basis that governs its existence, so they decrease gradually day by day. Moreover, the resolution of cases that have occurred in the lives of people in South Sumatra, especially those relating to cases of violation of local customs, has been returned to the Village Government together with the local custom leaders.

\section{REFERENCE}

\section{Books}

Fadli, Moh. et.al, Pembentukan Peraturan Desa Partisipatif (Head To A Good Village Governance), Penerbit UB Press, Cetakan Kedua Februari, 2013, Malang.

Huda, Ni'matul, Hukum Pemerintahan Desa (Dalam Konstitusi Indonesia Sejak Kemerdekaan Hingga Era Reformasi), (Penerbit Setara Press, Malang, Maret, 2015)

Soekanto, Soerjono, Hukum Adat Indonesia, (PT Raja Grafindo Persada, $15^{\text {th }}$ Ed, Jakarta, 2016)

Solekhan, Moch., Penyelenggaraan Pemerintahan Desa (Berbasis Partisipasi Masyarakat), (Penerbit Setara Press, $1^{\text {st }}$ Ed, Malang, 2014)

Zoem, Yusnani Hasyim et.al, Hukum Pemerintahan Daerah, (Jakarta; 
Raja grafindo Persada, Maret 2017)

\section{Journal}

Abubakar, Lastuti, 'Revitalisasi Hukum Adat Sebagai Sumber Hukum Dalam Membangun Sistem Hukum Indonesia', (2013) 13(2) Jurnal Dinamika Hukum.

Boag, Carly, 'A Comparative Study Of The Legal Frameworks Facilitating Indigenous Land Management In Postcolonial Societies: Indigenous Australia And Indonesian Adat Law', (2016) 3(2) Brawijaya Law Journal.

Syamsudin, M., 'Beban Masyarakat Adat Menghadapi Hukum Negara',
(2008) 15(3) Jurnal Hukum, 338351.

Sulistriyono and Sartika Intaning Pradhani, 'Pemikiran Hukum Adat Djojodigoeno dan Relevansinya Kini', (2018) 30(3) Jurnal Mimbar Hukum.

Tamarasari, Desi, 'Pendekatan Hukum Adat Dalam Menyelesaikan Konflik Masyarakat Pada Daerah Otonomi', (2002) 2(1) Jurnal Kriminologi Indonesia.

\section{Dictionary and Compilation}

Kompilasi Adat Istiadat, Banyuasin Sedulang Setudung, Kabupaten Banyuasin Tahun 2015. 